\title{
Measuring the impact of HRM on organisational performance
}

\author{
Anastasia A. Katou \\ University of Macedonia (GREECE) \\ akaton@,uom.gr
}

Received September 2008

Accepted December 2008

\begin{abstract}
The purpose of this paper is to measure the impact of HRM on organisational performance in the context of Greece. Data were collected from 178 organisations using a questionnaire survey in the Greek manufacturing sector, and analysed using the 'structural equation modelling' methodology. The results indicated that the relationship between HRM policies (resourcing and development, compensation and incentives, involvement and job design) and organisational performance is partially mediated through HRM outcomes (skills, attitudes, behaviour), and it is influenced by business strategies (cost, quality, innovation). Thus, the contribution of this study for academics and practitioners is that HRM policies associated with business strategies will affect organisational performance through HRM outcomes.
\end{abstract}

Keywords: HRM policies, organisational performance, Greece

\section{Introduction}

Over the last ten years significant steps forward have been made in identifying the HRM - performance relationship. However, serious gaps in our understanding still remain with respect to the causal ordering of the variables involved in the HRM performance relationship (Purcell, Kinnie, Hutchinson, Rayton, \& Swart, 2003; Wright, Gardner, Moyniham, \& Allen, 2005). Specifically, in analysing the impact of HRM on organisational performance, each of the HRM-performance linkage models developed complements the others by adding constructs, variables or relationships (Alcazar, Fernandez, \& Gardey, 2005). A serious limitation that recent reviews of 
the literature points out is that the link between HRM and organisational performance is considered like a 'black box', i.e., lack of clarity regarding 'what exactly leads to what' (Gerhart, 2005). It was further argued that it is important to consider the intervening steps in the HRM-performance relationship, or to consider the variables mediating or moderating the endpoint variables (Becker \& Gerhart, 1996).

Furthermore, Boselie, Dietz and Boon (2005), by analysing the literature over the last years on the HRM-performance relationship, reported wide disparities in the treatment of the components emphasising the "black box" stage between HRM and performance. They indicated that the theoretical frameworks which dominated the field were the "contingent framework" (i.e., HRM influences performance in relation to contingent factors such as business strategies) (Schuler \& Jackson, 1987), the resource-based view (i.e., HRM influences performance according to the human and social capital held by the organisation) (Barney, 1991) and the AMO theory (i.e., HRM influences performance in relation to employees' Ability, Motivation and Opportunity to participate) (Appelbaum, Bailey, Berg, \& Kalleberg, 2000).

Moreover, considering that there was no agreement on the HRM practices, policies, and systems employed, and accordingly the constructs developed, Boselie et al. (2005), Lepak, Liao, Chung and Harden (2006), and Wright et al. (2005) argued that the results derived from these studies were not comparable. Specifically, although there were attempts to create 'HRM checklists', these lists were not generally accepted due to the different context and concept of HRM employed by the authors of the studies. Additionally, the HRM-outcomes categorised as "employee skills" (employee competences, including cooperation), "employee attitudes" (motivation, commitment, satisfaction) and "employee behaviour" (retention, presence), were the usually employed sets of mediating variables (Paauwe, 2004; Lepak et al., 2006). However, the studies considering HRMoutcomes as mediating variables also produced mixed results with respect to causation (Wright et al., 2005).

In summary, it may be argued that while there is a growing body of theory and empirical research demonstrating relationships between HRM policies, collective employee attributes, and firm outcomes, additional studies in this area are needed (Harter, Schmidt, \& Hayes, 2002; Purcell \& Kinnie, 2007). Furthermore, although it was accepted that HRM is positively related to organizational performance, there is 
a great need for additional evidence to support the HRM-performance relationship from different contexts (Gerhart, 2007).

Specifically, while a few investigations have been initiated in emerging markets and in transitional countries (Ahlstron, Foley, Young, \& Chan, 2005; Zupan \& Kase, 2005), the literature highlights that most of the studies examining the relationship between HRM and organisation's performance have been conducted in the United States and the United Kingdom (Huselid, 1995; Guest, Michie, Conway, \& Sheehan, 2003). To fill this gap and to further examine the process through which HRM policies impact organisational performance, it is important to conduct analysis in non-US/UK context. Thus, the purpose of this paper is to investigate how HRM influences organisational performance and, for a better understanding of the relationship between these two variables, to take into account that business strategies influence HRM in the Greek manufacturing context. The remaining paper is structured as following. Next we present the operational model and the hypotheses to be tested. This is followed by a discussion on the methodology adopted for this study. The next sections concentrate on the key results, discussion, and practical implications of the study. Finally, we summarise the main conclusions of the study and highlight the main contributions, limitations of the analysis and propose directions for further research.

\section{Operational model and hypotheses}

Figure 1 depicts an operational model linking HRM to organisational performance. The model is adapted from Paauwe and Richardson (1997), which argues that HRM outcomes mediate the relationship between HRM activities and firm performance, and Katou and Budhwar (2006), which recognises that HRM outcomes connect HRM policies to business performance, and furthermore it assumes that HRM policies and business strategies are independent. The proposed model is blending insights from the theories of contingency, resourced-based view and AMO into an overall theory of HRM (Boselie et al., 2005), and contrary to Katou and Budhwar (2006) it hypothesises that HRM policies are influenced by business strategies. Specifically: 


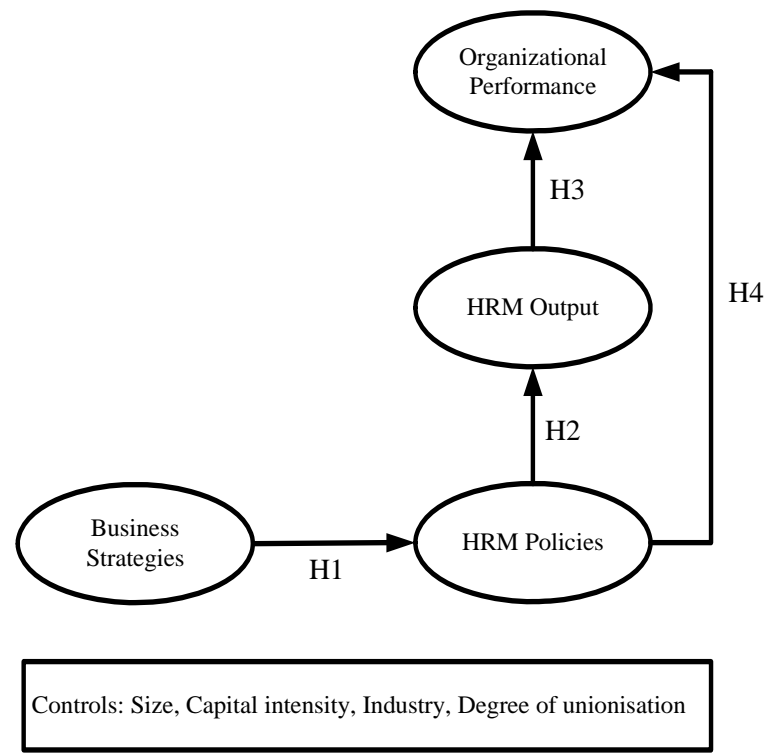

Figure 1. "The operational HRM-performance linkage model".

We propose that an organisation's set of HRM policies will be effective if it is consistent with other business strategies (Gomez-Mejia \& Balkin, 1992), suggesting that business strategies are followed by HRM policies in determining business performance (contingency perspective). Porter's (1985) generic business strategies of cost reduction, quality enhancement and innovation, for an organisation to gain and retain competitive advantage, could be obvious candidates. Specifically, a cost business strategy ambiguously (positive, zero, negative) influences the relationship between HRM policies and organisational performance, a quality business strategy positively influences the relationship between HRM policies and organisational performance, and an innovation business strategy positively influences the relationship between HRM policies and organisational performance (Schuler \& Jackson, 1987). Thus, we may hypothesise that:

- Hypothesis 1. Business strategies influence HRM policies in determining business performance.

HRM policies may play an important role in building the organisation's human capital pool by developing its rare, inimitable and non-substitutable internal resources (resource-based view). According to the resource-based view, HRM policies have a direct impact on employee attributes such as skills, attitudes and behaviour, the so-called HRM outcomes, which are subsequently translated into 
improved organisational performance (Boxal \& Steeneveld, 1999). However, according to the contingency theory, it may not be always like this, because of the influence of external factors. Nevertheless, theoretical and empirical work in the field of HRM (Purcell at al., 2003; Lepak et al., 2006) suggests that according to the AMO perspective the HRM system of employees' "ability to perform" (e.g., selection, training, performance appraisal) influences their "skills" (competence, including cooperation), the HRM system of employees' "motivation to perform" (e.g., compensation, promotion, incentives) influences their "attitudes" (motivation, commitment, satisfaction), and the HRM system of employees' "opportunity to perform" (work design, participation, involvement, communication) influences their "behaviour" (retention, presence). Thus, we may hypothesise that:

- Hypothesis 2. A relationship exists between HRM policies and HRM outcomes.

The philosophy of the AMO perspective is that HRM policies encompasses mediating changes in employees' abilities, motivations, and opportunities to participate that positively influence organisational performance, illuminating thus the "black box" in the HRM-performance relationship (Boselie et al., 2005; Purcell \& Hutchinson, 2007). However, it is argued that there must be enough employees with the required skills, experience and knowledge to do all the necessary work for the benefit of the organisation (Appelbaum et al., 2000). Moreover, it is argued that in order to bring lasting and better results and to significantly contribute to the success of their organisation, employees must be motivated, committed, and satisfied (Paul \& Anantharaman, 2003; Paauwe, 2004). Additionally, it is accepted that unless the organisation is able to retain its employees, it will not be able to capitalize on the human assets developed within the organisation. Thus, employee retention and employee presence may have a positive impact on organisational effectiveness (Boselie, Paauwe, \& Jansen, 2001). Thus, we may hypothesise that:

- Hypothesis 3.Improvements in HRM outcomes mediate the relationship between HRM policies and organisational performance.

Considering the discussion thus far the HRM policies (or systems) may influence organisational performance indirectly through HRM outcomes. However, a direct effect of HRM policies on organisational performance may also be present (Katou \& Budhwar, 2007), implicitly accepting the arguments of Huselid and Becker (1996), 
who support that a causal relationship exists from HRM policies to organisational performance, and of Delery and Doty (1996), who further assume that the relationship between HRM policies and organisational performance is linear, thus implying that there is no synergic interdependence of the different HRM policies, but the effect of the HRM policies on organisational performance is additive (Becker $\&$ Gerhart, 1996). Thus, we may hypothesise that:

- Hypothesis 4. A positive relationship exists between HRM policies and organisational performance.

Several controls, such as 'size', 'capital intensity', 'industry' and 'union intensity', may influence the adoption of business strategies and HRM policies, and have an impact on HRM outputs and organisational performance (Paauwe \& Richardson, 1997). This means that organisations do not operate in a vacuum, but controls may influence the adoption of business strategies and HRM policies, and may have a positive or negative impact on HRM outputs and organisational performance (Huselid, 1995).

In summary, the causal pathway indicated by the operational model in Figure 1, refers to an 'indirect linkage' through HRM outcomes, between HRM policies and organisational performance, and to a 'direct linkage', between HRM policies and organisational performance. However, it is not required these linkages to be simultaneously present. It is very possible even in the absence of a direct linkage, some policies to significantly contribute to business performance through the intervening process. Furthermore, business strategies influence HRM policies, and the whole process may be 'moderated' by organisational level controls (Paauwe and Richardson, 1997).

\section{Methodology}

\subsection{Sample}

A large questionnaire survey in 23 industries in the Greek manufacturing sector was carried out. A sample of 600 organisations was used from the main Greek directory - ICAP Group, which is the only Greek company recognized by the Bank of Greece as an External Credit Assessment Institution and includes incorporated and limited liability companies. The sample was obtained by employing the stratified methodology. The strata were the 23 manufacturing sector industries 
including organisations with more than 20 employees. 20 percent of the approximately 3000 organisations were randomly chosen from each stratum of the directory. Using personal connections-samplers, the questionnaires were taken personally to organizations. One hundred and seventy eight (178) usable questionnaires in terms of completeness were received, a response rate of approximately 30 percent. The distribution of the sample organisations with respect to the industrial sector was similar to the distribution of the population organisations (see Table 1).

\begin{tabular}{|c|c|c|c|c|}
\hline \multirow[t]{2}{*}{ I ndustries } & \multicolumn{2}{|c|}{ Sample organisations } & \multicolumn{2}{|c|}{$\begin{array}{c}\text { Population organisations with } \\
\text { more than } 20 \text { employees listed in } \\
\text { the ICAP Directory }\end{array}$} \\
\hline & Frequency & Percent & Frequency & Percent \\
\hline 1 Food products & 31 & 17.4 & 529 & 17.9 \\
\hline 2 Beverages & 10 & 5.6 & 76 & 2.6 \\
\hline 3 Tobacco & 0 & 0.0 & 19 & 0.6 \\
\hline 4 Tobacco products & 0 & 0.0 & 6 & 0.2 \\
\hline 5 Textiles and textile products & 12 & 6.7 & 229 & 7.8 \\
\hline 6 Linen & 2 & 1.1 & 21 & 0.7 \\
\hline 7 Wearing apparel & 20 & 11.2 & 303 & 10.3 \\
\hline 8 Footwear & 2 & 1.1 & 48 & 1.6 \\
\hline 9 Leather products & 1 & 0.6 & 5 & 0.2 \\
\hline 10 Wood and cork & 2 & 1.1 & 50 & 1.7 \\
\hline 11 Pulp and paper & 2 & 1.1 & 72 & 2.4 \\
\hline 12 Petroleum products & 2 & 1.1 & 10 & 0.3 \\
\hline 13 Chemicals & 9 & 5.1 & 88 & 3.0 \\
\hline 14 Pharmaceuticals & 7 & 3.9 & 84 & 2.8 \\
\hline 15 Rubber and plastic products & 11 & 6.2 & 164 & 5.6 \\
\hline 16 Non-metallic mineral products & 21 & 11.8 & 302 & 10.2 \\
\hline 17 Basic metal industries & 3 & 1.7 & 18 & 0.6 \\
\hline 18 Metal products. except machinery & 12 & 6.7 & 270 & 9.2 \\
\hline 19 Machinery and equipment & 6 & 3.4 & 86 & 2.9 \\
\hline 20 Office machinery and computers & 8 & 4.5 & 115 & 3.9 \\
\hline 21 Electrical equipment & 3 & 1.7 & 79 & 2.7 \\
\hline 22 Electrical machinery & 2 & 1.1 & 61 & 2.1 \\
\hline $\begin{array}{l}\text { Motor and other transport } \\
\text { equipment }\end{array}$ & 3 & 1.7 & 99 & 3.4 \\
\hline 24 Furniture & 6 & 3.4 & 103 & 3.5 \\
\hline 25 Other & 3 & 1.7 & 112 & 3.8 \\
\hline Total & 178 & 100.0 & 2949 & 100 \\
\hline
\end{tabular}

Table 1. "Main activities of the organisations in sample and population".

Most of the questions for the survey were drawn from existing international HRM surveys, such as the Price Waterhouse Cranfield Project Survey (Brewster \& Hegewisch, 1994) and Hall and Torrington (1998), and generally from Phillips (1996), Othman (1996), Budhwar and Sparrow (1997), Sanz-Valee, SabaterSanchez, and Aragon-Sanchez (1999), and Richardson and Thompson (1999). The 
questionnaire was originally developed in English, then, it was translated into Greek, and finally translated back from Greek to English. The translated questionnaire was piloted in 10 organisations, and it was handed to the CEO, or Personnel Officers, or Financial Officers of the sample organisations due to the reluctance of Greek respondents to complete and return the questionnaires and due to the fact that employees are flooded with questionnaires. However, the survey questionnaire was completed by one person responsible in each firm for the HRM function. We acknowledge this as a limitation. However, the application of Harman's single factor test (Harman, 1967) to all the relevant variables in the model, using the eigenvalue greater than one criterion, revealed seven factors, and not just one, with the first factor explaining 26.9 percent of the variance in the data which is not relatively very high. According to this test if a significant amount of common method bias exists in the data, then the factor analysis of all the relevant variables in the model will generate a single factor that accounts for most of the variance. Thus, we believe that the common method bias in the data was relatively limited.

\subsection{Measures}

All variables used in the study are presented in column one of Table 2 . Specifically:

\section{Organisational performance variables}

We used multiple organisational performance variables (Chenhall \& LangfieldSmith, 2007) which were measured under the philosophy of a perceived rating of the organisation's performance on a five point scale ranging from $1=$ very bad to 5 $=$ very good. Recognising the potential problems with self-report measures, to ensure the reliability and the validity of the indexes and to minimize random fluctuations and anomalies in the data the respondents were asked to report performance over the past 3 years. The specific items constituting the organisational performance construct are as follows: "effectiveness", if the organisation meets its objectives; "efficiency", if the organisation uses the fewest possible resources to meet its objectives; "development", if the organisation is developing in its capacity to meet future opportunities and challenges; "satisfaction", of all participants (stakeholders, employees, and customers); "innovation", for products and processes; "quality", per cent of products of high quality. 


\section{$\underline{\text { HRM policies }}$}

The precise evaluation of the HRM-performance relationship requires reliable and valid assessment of HRM policies (Gardner, Moyniham, Park, \& Wright, 2001; Harney \& Jordan, 2008). The accurate measurement of the HRM policies will feed the "black-box" in the HRM-performance relationship. Thus, respondents were not asked about the presence or not of the HRM policies but about the effectiveness (measured on a five point scale, where $1=$ not at all effective to $5=$ highly effective) of the used HRM policies, as it refers to "how well the HR practice is performing" (Huselid, Jackson, \& Schuler, 1997). However, although there are countless combinations of HRM policies that result in identical organisational outcomes (Delery \& Doty, 1996) and although identifying exactly which HRM policies are associated with superior firm performance has been disappointing (Katou \& Budhwar, 2007), the items used to constitute the HRM policies construct refer to the usual four key areas of resourcing, development, reward, and relations, in which human resources strategies may be developed (Armstrong, 1996).

\section{HRM outcomes}

We used multiple HRM outcome variables which were measured under the philosophy of a perceived rating on a five point scale ranging from $1=$ very bad to 5 = very good. The specific items constituting the HRM outcome construct are as follows: competence, employees cooperation with management, and cooperation among employees, indicating thus employee skills; motivation, commitment, and satisfaction, indicating thus employee attitudes; retention, and presence, indicating thus employee behaviours. Employees' cooperation is usually indicated in skills following Batt (2002: 587) who suggests that employees "use their skills in collaboration with other workers", and arguing that although competencies are assumed to be foundational to all performance improvement, they are not sufficient for improving organizational performance unless employees are cooperated (Lopez, Peon, \& Ordas, 2005).

\section{Business strategies}

Business strategies were measured by eight items on a five point scale, ranging from $1=$ not very important to $5=$ totally essential, which define potential competitive priorities in manufacturing (Snell \& Dean, 1992). Using factorial 
analysis these eight items were reduced into three business strategy dimensions, which we labelled cost, quality and innovation (Porter, 1985). The cost dimension comprises the cost reduction item; the quality dimension comprises the customer service, distribution channels, quality enhancement, and brand image items; the innovation dimension comprises the innovation, improvement of goods, and wide range of products items (Sanz-Valee et al., 1999).

\begin{tabular}{|l|c|c|}
\hline Variables / Constructs & $\begin{array}{c}\text { Cronbach } \\
\text { Alpha }\end{array}$ & $\begin{array}{c}\text { Percent of } \\
\text { variance } \\
\text { explained }\end{array}$ \\
\hline $\begin{array}{l}\text { HRM Policies } \\
\text { Selection, Training and Development, Performance appraisal, } \\
\text { Compensation, Promotion, Incentives, Work design, Participation, } \\
\text { Involvement, Communication }\end{array}$ & 0.926 & 70.166 \\
\hline $\begin{array}{l}\text { HRM Outcomes } \\
\text { Competence, Cooperation with management, Cooperation among } \\
\text { employees, Motivation, Commitment, Satisfaction, Retention, } \\
\text { Presence }\end{array}$ & 0.952 & 74.928 \\
\hline $\begin{array}{l}\text { Business Strategies } \\
\text { Cost reduction, Quality enhancement, Innovation }\end{array}$ & 0.577 & 56.823 \\
\hline $\begin{array}{l}\text { Organisational Performance } \\
\text { Effectiveness, Efficiency, Development, Satisfaction, Innovation, } \\
\text { Quality }\end{array}$ & 0.929 & 80.810 \\
\hline $\begin{array}{l}\text { Controls } \\
\text { Size, Capital intensity, Industry, Degree of unionisation }\end{array}$ & & \\
\hline
\end{tabular}

Table 2. "Variables of the survey instrument".

\section{Controls}

The control variables included in the analysis are as follows: 'size' (in natural logarithms); 'capital intensity' (natural logarithm of total assets by total employment); 'industry' is represented by a two level variable, classifying 78 organisations as being 'traditional' (food products, beverages, textiles and textile products, linen, wearing apparel, footwear, and leather products) because the primary inputs for their production come from the agricultural sector, which is the traditional sector in Greece, and the rest 100 organisations as being 'nonagricultural' (chemical, metallic products, office machinery, electrical equipment, etc.) because the primary inputs for their production do not come from the agricultural sector; the 'degree of unionisation' is represented by the proportion of staff in the organisation that is members of a trade union (i.e., $1=0 \%, 2=1$ $25 \%, 3=26-50 \%, 4=51-75 \%$, and $5=76-100 \%$ ). 


\subsection{Consistency of the survey instrument}

Construct internal consistency was checked by computing Cronbach (1951) alphas. The figures in Table 2 indicate that the survey instrument is a reliable instrument for checking the model presented in Figure 1, because all Cronbach alphas, except for the 'business strategies' construct, are much higher than 0.70 (Nunnally, 1978). However, considering values as low as 0.35 that have been found acceptable when used with other measures (Roberts \& Wortzel, 1979), we decided to maintain the business strategy construct in spite of its low reliability. Construct validity was examined by evaluating the percent of the total variance explained per dimension obtained by applying confirmatory factor analysis (CFA) using LISREL (Jöreskog \& Sörbom, 2004). The percent of total variance explained values reported in Table 2, are much higher than 50.0\% indicating acceptable survey instrument construct validity (Hair, Anderson, Tatham, \& Black, 1995). However, before the CFA we preferred not carry out an exploratory factor analysis to identify possible structures a priori, but instead to rely on content validity, which ensures that the measure includes an adequate and representative set of items that would tap the concept (Sekaran, 1992).

\subsection{Statistical analysis}

To test the raised hypotheses of the proposed framework the methodology of 'structural equation models' (SEM) or 'latent variable models' (Hair et al., 1995) was used, via LISREL and the maximum likelihood estimation (MLE) (see Jöreskog $\&$ Sörbom, 2004). SEM is effective when testing models that are path analytic with mediating variables, and include latent constructs that are being measured with multiple items (Luna-Arocas \& Camps, 2008). We used MLE because tests of departure from normality, skewness and kurtosis for all variables used were (except for 'industry' and 'union intensity') within acceptable statistical limits. Furthermore, the sample size of 178 in this study is within the range of 100 to 200 for using MLE procedures. We must note here that in our experiments we kept the variables of industry and union intensity although they were not within acceptable statistical limits. Although this decision may have reduced the effectiveness of the MLE, all controls were found later to be not significant and thus they were not used in the final estimation. 
We assessed the overall model fit following Bollen's (1989) recommendation to examine multiple indices, since it is possible for a model to be adequate on one fit index but inadequate on many others. We used the chi-square and the normed-chisquare tests, the goodness of fit index (GFI), and we examined the root mean squared error of approximation (RMSEA) (Jöreskog \& Sörbom, 2004). A nonsignificant chi-square (i.e. $p>0.05$ ) indicates that the proposed model is an adequate presentation of the entire set of relationships. However, in cases of significant chi-squares and high numbers of degrees of freedom, the value of the normed-chi-square (i.e. value of chi-square / degrees of freedom) should be used. The most flexible acceptance value of the normed chi-square must not be higher than 5 , but to be more cautious it should not go above 3 (Pedhazur \& PedhazurSchelkin, 1991). The GFI should not go lower than 0.70 in the case of complex models (Judge \& Hulin, 1993). The RMSEA considers the fit of the model to the population covariance / correlation matrix and a value of RMSEA less than 0.08 represents a good approximation respectively. Furthermore, the normed fit index (NFI) (Bentler \& Bonett, 1980) and the comparative fit index (CFI) (Bentler, 1990) are also used, for investigating the structure that best fits the empirical data. These indexes should not go lower than 0.90 , but in complex models the lowest acceptable level for the NFI and CFI is 0.80 (Hart, 1994).

\section{Results}

The estimated path diagram for the proposed HRM - performance link framework (presented in Figure 1) is presented in Figure 2. The boxes represent exogenous or endogenous observed variables and the circles represent the related latent variables. The light arrows indicate the observed variables that constitute the related latent variables and the bold arrows indicate the structural relationships between the corresponding variables. The numbers that are assigned to each arrow show the significant estimated standardised coefficients. We must remind here that in order to keep the model as simple as possible without loosing its validity, we followed Paawue and Richardson (1997) and we did not group the HRM policies into their relevant areas of resourcing, development, rewards, and relations, and the HRM outcomes into their relevant areas of skills, attitudes, and behaviours.

The goodness-of-fit indexes confirmed the validity of the operational model (Normed-Chi-Square $=2.74, \mathrm{RMSEA}=0.099, \mathrm{NFI}=0.96, \mathrm{CFI}=0.95, \mathrm{GFI}=$ $0.68)$, although flexible levels for RMSEA and GFI were attained. We must note 
here that before we conclude on the results presented in Figure 2 we tried all possible paths for linking controls with business strategies, HRM policies, HRM outcomes, and organisational performance, but the results with respect to contingencies were not significant. As shown in Figure 2:

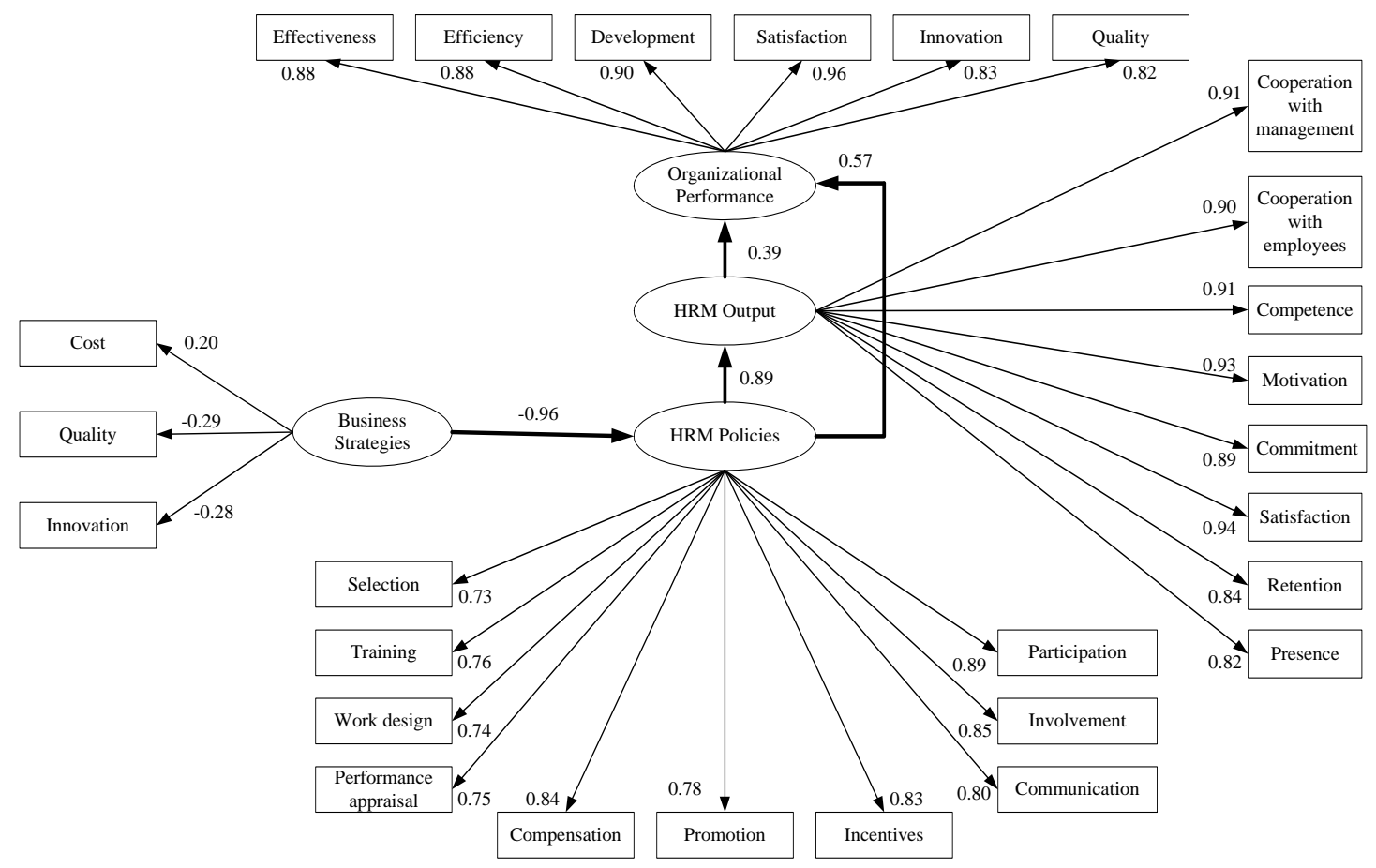

Chi-Square $=1018.32 \mathrm{df}=372 \mathrm{p}$-value $=0.000$ Normed Chi-Square $=2.7374$ RMSEA $=0.099 \mathrm{CFI}=0.96 \mathrm{NFI}=0.95 \mathrm{GFI}=0.68$

Figure 2. "The estimated model using LISREL".

- With respect to business strategies, cost strategies have a direct negative effect on HRM policies $(-0.96 \times 0.20=-0.192)$, whilst quality $(-0.96 \times-$ $0.29=0.278)$, and innovation $(-0.96 \times-0.28=0.269)$ strategies, have positive direct effects on HRM policies, supporting thus hypothesis $\mathrm{H} 1$.

- HRM policies have a direct positive effect on HRM outcomes (0.89), supporting thus hypothesis $\mathrm{H} 2$.

- HRM outcomes have a direct positive effect on organisational performance (0.39), giving hence support to hypothesis H3.

- HRM policies have a direct positive effect on organisational performance (0.57), giving hence support to hypothesis $\mathrm{H} 4$. 


\section{Discussion}

The results in Figure 2 support all the hypotheses stated above. However, two are the main subjects that should be differentiated in this study: (a) the intervening steps in the HRM-performance relationship, and (b) the variables moderating the endpoint variables of this relationship. With respect to the first subject the findings show that HRM outcomes partially mediate the relationship between HRM policies and organisational performance, indicating thus that both a direct and an indirect linkage exists between HRM policies and organisational performance (Huselid, 1995). Considering the second subject the findings support the contingency perspective, since business strategies influence HRM policies.

Specifically, the crucial factor in the HRM-performance relationship is how HRM policies shape discretionary behaviour, i.e., the choices people often make about the way their work is done, which are neither expected nor required, and therefore cannot officially rewarded or punished by the organisation for their presence or absence, which is translated into improved organisational performance (Purcel et al. 2003). AMO theory is regarded to be the heart of strategic human resources management in the sense that organisations looking for improving performance develop HRM policies in the domains of resourcing and development, compensation and incentives, and involvement and job design that are designated to positively shape discretionary behaviour (Boxall \& Purcell, 2003; Lepak et al., 2006). HRM outcomes such as employee skills (competences, including cooperation), employee attitudes (motivation, commitment, satisfaction), and employee behaviours (retention, presence) mediate HRM policies and discretionary behaviour (Purcel et al. 2003). However, authors such as Gardner, Moyniham, Park and Wright (2001), and Purcell and Hutchinson (2007) argue that in the HRM-performance causal chain it is not HRM outcomes that affect organisational performance, but may exist a serial causation from employee skills, to attitudes and then to behaviours that finally affect organisational performance. Nevertheless, in this study it has been hypothesised and verified that HRM outcomes simultaneously affect organisational performance (Paauwe \& Richardson, 1997). Thus, in order to improve organisational performance the levels of satisfaction, commitment and motivation should be improved.

Furthermore, in terms of mediation, we found that skills, attitudes, and behaviour mediate the relationship between HRM policies and organisational performance, 
supporting thus the argument that HRM policies influence organisational performance by creating a workforce that is skilled and has the right attitudes and behaviour, supporting thus the findings of Delery and Doty (1996). It also partially supports Guest (2001) for satisfaction and commitment and Boselie et al.(2001) for satisfaction and motivation. Moreover, our findings also support the basic equation in the HRM-performance relationship, which indicates that HRM policies directly influence organisational performance (Boselie et al., 2005). Thus, considering that a direct linkage and an indirect linkage, through HRM outcomes, simultaneously exist between HRM policies and organisational performance, it is concluded that HRM outcomes partially mediate the relationship between HRM policies and organisational performance (Baron \& Kenny, 1986).

Turning now to the second subject, the study provides support for the contingency perspective with respect to business strategies. Analytically, the results reveal that it is possible that the application of a cost strategy has a negative impact on organisational performance due to tight control on costs, which may de-motivate people in their employees function, producing therefore lower organisational performance (Katou \& Budhwar, 2006). However, organisational performance should not be confused with financial performance. Although organisational performance may be lower, due to the application of the cost strategy, financial performance may be higher, due to the fact that financial performance is a 'reduced form variable' of profits minus costs (Kintana, Alonso, \& Verri, 2003).

Organisations with an innovation strategy afford higher rewards due to their ability to attract the qualified flexible, creative and skilled people necessary for their development. Organisations that follow innovative strategies put emphasis in promotion arrangements, because they have more need of a longer-term orientation of employees (Schuler \& Jackson, 1987). With respect to employee relations, organisations that follow an innovation or quality strategy put emphasis in employee participation, involvement and communication, because they need creative and flexible personnel (Sanz-Valee et al., 1999). Moreover, organisations with an innovation strategy put high emphasis on employee participation in order to keep its sophisticated labour force satisfied. Similarly, organisations with a quality strategy pay extensive attention to training and development in order to stimulate co-operation and obtain the continuous improvement that quality implies (Deming, 1986). 
Furthermore, considering that the business strategy standardised coefficients are rather large enough (-0.192 for cost, 0.278 for quality, 0.269 for innovation) it seems that Porter's (1985) generic strategies used in the study are relatively powerful predictors of organisational performance (Youndt et al., 1996). Specifically, quality and innovation strategies are expected to reinforce organisational performance, although indirectly through the HRM-performance relationship, considering that the organisation is capitalising its intellectual capital and requiring its employees to become knowledge workers (Snell \& Dean, 1994; Youndt et al., 1996), whilst additionally, cost strategies are expected to ease organisational performance in the Greek context (Katou \& Budhwar, 2006).

\section{Conclusions}

Although past research has demonstrated that there exists a relationship between HRM policies and organisational performance (e.g., Kalleberg \& Moody, 1994; Harel \& Tzafrir, 1999), it has neglected to investigate the mediating mechanisms, usually called the "black box", through which HRM policies are hypothesised to affect organisational performance. The testing of which HRM policies to be used in a study in new contexts is of much importance (Lepak et al., 2006). Although little is known about the so-called "black box" that lies between the two end points of the HRM-performance relationship (Wright \& Gardner, 2003), i.e. HRM as input and performance as output, this study treats the black box as a mediating stage in the HRM-performance relationship, considering as well that HRM policies are also influenced by contingencies such as business strategies.

The operational model in this study advocates that HRM policies directly influence HRM outcomes such as collective skills, attitudes, and behaviours, and thus, indirectly through HRM outcomes improve organisational performance. Furthermore, it argues that HRM policies are significantly, positively and directly related to organisational performance. In addition, it assumes that HRM policies are influenced by business strategies. Thus, the findings of this study support that the relationship between HRM policies and organisational performance is partially mediated through HRM outcomes, and HRM policies are moderated by business strategies.

This study has a number of clear implications for both managers and decision makers. Notably, the major implications of the study are as follows. 
- Realising that business strategies and HRM policies are not mutually independent, organisations should develop HRM policies with respect to the business strategies they follow. For achieving this, companies should have HRM departments and representation of these departments at the board level.

- Organisational performance depends heavily on HRM outcomes such as skills, attitudes and behaviour. Thus, the emphasis of the development of HRM policies and business strategies should be directed in improving these HRM outcomes.

- Participation, involvement, compensation, incentives, communication, promotion, training and development, performance appraisal, work design, and selection may constitute in a descending order the important aspects of the HRM strategy.

- Quality, innovation, and cost may constitute in a descending order the important aspects of the business strategy.

- Satisfaction, motivation, competence, cooperation with management, cooperation among employees, commitment, retention, and presence may constitute in a descending order the important aspects of the HRM outcomes.

The conclusions above, nonetheless, should be treated with caution. This is mainly because a single respondent from each organisation provided information on business strategy, HRM policies, HRM outcomes, and perceived measures of organisational performance. Respondent bias may have set in the form of upward or downward reporting of the measures. In spite of such limitations, the study makes some important contributions. It tests theoretical assumptions in smaller firms and in a non- USA/UK context and it provides support for the perspective that HRM outcomes partially mediate the relationship between HRM policies and organisational performance, considering as well that business strategies influence HRM policies. 


\section{References}

Ahlstron, D., Foley, S., Young, M.N., \& Chan, E.S. (2005). Human resource strategies in post WTO China. Thunderbird International Business Review, 47, 263-325.

Alcazar, F.M., Fernandez, P.M.R., \& Gardey, G.S. (2005). Researching on SHRM: An analysis of the debate over the role played by human resources in firm success. Management Revue, 16, 213-241.

Appelbaum, E., Bailey, T., Berg, P., \& Kalleberg, A.L.(2000). 'Manufacturing advantage: Why high-performance work systems pay off'. London: Economic Policy Institute: Cornell University Press.

Armstrong, M. (1996). A handbook of personnel management practice. London: Kogan Page.

Barney, J.B. (1991). Firm resources and sustainable competitive advantage. J ournal of Management, 17, 99-120.

Baron, R.M., \& Kenny, D.A. (1986). The moderator-mediator variable distinction in social psychological research: conceptual, strategic, and statistical considerations. J ournal of Personality and Social Psychology, 51, 1173-1182.

Batt, R. (2002). Managing customer services: Human resource practices, quit rates, and sales growth. Academy of Management J ournal, 45, 587-597.

Becker, B.E., \& Gerhart, B. (1996). The impact of human resource management on organisational performance: progress and prospects. Academy of Management Journal, 39, 779-801.

Bollen, K.A. (1989). Structural Equations with Latent Variables. New York: Wiley.

Bentler, P.M. (1990). Comparative Fit Indexes in Structural Models. Psychological Bulletin, 107, 238-246.

Bentler, P.M., \& Bonett, D.G. (1980). Significance Test and Goodness of Fit in the Analysis of Covariance Structures. Psychological Bulletin, 88, 588-606. 
Boselie, P., Dietz, G., \& Boon, C. (2005). Commonalities and contradictions in HRM and performance research. Human Resource Management J ournal,15, 67-94.

Boselie, P., Paauwe, J., \& Jansen, P. (2001). Human resource management and performance: lessons from the Netherlands. International Journal of Human Resource Management,12, 1107-1125.

Boxall, P., \& Purcell, J. (2003). Strategy and human resource management. Basingstoke: Palgrave Macmillan.

Boxall, P., \& Steeneveld, M. (1999). Human resource strategy and competitive advantage: A longitudinal study of engineering consultancies. Journal of Management Studies, 36, 443-463.

Brewster, C., \& Hegewisch, A. (1994). Hunan resource management in Europe: Issues and opportunities. In C. Brewster and A. Hegewisch (eds.). Policy and practice in European human resource management: The Price Waterhouse Cranfield Survey. London: Routledge.

Budhwar, P., \& Sparrow, P.R. (1997). Evaluating levels of strategic integration and development of human resource management in India. The International Journal of Human Resource Management, 8, 476-494.

Chenhall, R.H., \& Langfield-Smith, K. (2007). Multiple perspectives of performance measures' European Management J ournal, 25, 266-282.

Cronbach, L.J. (1951). Coefficient Alpha and the Internal Structure of Tests. Psychometrika, 16, 297-334.

Delery, J., \& Doty, D.H. (1996). Modes of theorizing in strategic human resource management: test of universalistic, contingency and configurational performance predictions. Academy of Management J ournal, 39, 802-835.

Deming, W.E. (1986). Out of the crisis. Cambridge, MA: MIT Centre of Advanced Studies.

Gardner, T., Moyniham, L., Park, K., \& Wright, P. (2001). Beginning to unlock the black box in the HR-performance relationship: The impact of HR practices on 
employee attitudes and outcomes, CAHRS Working Paper, Ithaca, NY: Cornell University.

Gerhart, B. (2005). Human resources and business performance: Findings, unanswered questions, and an alternative approach. Management Revue, 16, 174-185.

Gerhart, B. (2007). Modeling HRM and performance linkages. In P. Boxall, J. Purcell, and P. Wright (eds). The Oxford Handbook of Human Resource Management. Oxford: Oxford University Press.

Gomez-Mejia, L.R., \& Balkin, D.B. (1992). Compensation, Organisational Strategy and Firm Performance.Cincinnati: Southwestern.

Guest, D.E. (2001). Human resource management: when research confronts theory.International J ournal of Human Resource Management, 12, 1092-1106.

Guest, D.E., Michie, J., Conway, N., \& Sheehan, M. (2003). Human resource management and corporate performance in the UK. British Journal of Industrial Relations, 41, 291-314.

Hair, F., Anderson, R., Tatham, R., \& Black, W. (1995). Multivariate Data Analysis with Readings. ( $4^{\text {th }}$ ed. $)$. London: Prentice-Hall.

Hall, L., \& Torrington, D. (1998). The human resource function: The dynamics of change and development. London: Financial Times/Pitman Publishing.

Harel, G.H., \& Tzafrir, S.S. (1999). The effect of human resource management practices on the perceptions of organisational and market performance of the firm. Human Resource Management, 38, 185-200.

Harman, H.H. (1967). Modern factor analysis. Chicago, IL: University of Chicago Press.

Harney, B., \& J ordan, C. (2008). Unlocking the black box: Line managers and HRMperformance in a call centre context'. International Journal of Productivity and Performance Management, 57, 275-296. 
Hart, P.M. (1994). Teacher Quality of Work Life: Integrating Work Experiences, Psychological Distress and Morale. Journal of Occupational and Organizational Psychology, 67, 109-132.

Harter, J.K., Schmidt, F.L., \& Hayes T.L. (2002). Business-unit-level relationship between employee satisfaction, employee engagement, and business outcomes: A meta-analysis. Journal of Applied Psychology, 87, 268-279.

Huselid, M.A. (1995). The impact of human resource management practices on turnover, productivity and corporate financial performance. Academy of Management J ournal, 38, 635-670.

Huselid, M.A., \& Becker, B.E. (1996). Methodological issues in cross-sectional and panel estimates of the human resource-firm performance link. Industrial Relations, 35, 400-422.

Huselid, M.A., Jackson, S.E., \& Schuler, R.S. (1997). Technical and strategic human resource management effectiveness as determinants of firm performance. Academy of Management J ournal, 40, 171-188.

Jöreskog, K.G., \& Sörbom, D. (2004). LISREL 8.7 for Windows [Computer Software]. Lincolnwood, IL: Scientific Software International, Inc.

Judge, T.A., \& Hulin, C.L. (1993). Job Satisfaction as a Reflection of Disposition: A multiple Source Causal Analysis. Organizational Behavior and Human Decision Processes, 56, 388-421.

Kalleberg, A.L., \& Moody, J. W. (1994). Human resource management and organisational performance. American Behavioural Scientist, 37, 948-962.

Katou, A.A., \& Budhwar, P.S. (2006). Human resource management systems and organisational performance: A test of a mediating model in the Greek manufacturing context. International Journal of Human Resource Management, 17, 1223-1253.

Katou, A.A., \& Budhwar, P.S. (2007). The effect of human resource management policies on organisational performance in Greek manufacturing firms. Thunderbird International Business Review, 49, 1-35. 
Kintana, M.L., Alonso, A.U., \& Verri, C.G.O. (2003). High performance work systems and firm's operational performance: The moderating role of technology. Working Paper. Public University of Navarra.

Lepak, D.P., Liao, H., Chung, Y., \& Harden, E.E. (2006). A conceptual review of human resource management systems in strategic human resource management research. Research in Personnel and Human Resources Management, 25, 217271.

Lopez, S.P., Peon, J.M.M., \& Ordas, C.J.V. (2005). Human resource practices, organizational learning and business performance. Human Resource Development International, 8, 147-164.

Luna-Arocas, R., \& Camps, J. (2008). A Model of High Performance Work Practices and Turnover Intentions, Personnel Review, 37, 26-46.

Nunnally, J.C. (1978). Psychometric Theory. New York: McGraw-Hill.

Othman, R.B. (1996). Strategic HRM: Evidence from the Irish Food Industry. Personnel Review, 21, 40-58.

Paauwe, J. (2004). HRM and performance: Achieving long-term viability. Oxford: Oxford University Press.

Paauwe, J., \& Richardson, R. (1997). Introduction: Special issue on HRM and performance. International Journal of Human Resource Management, 8, 257-262.

Paul, A.K., \& Anantharaman, R.N. (2003). Impact of people management practices on organisational performance. International Journal of Human Resource Management, 14, 1246-1266.

Pedhazur, E.J., \& Pedhazur-Schmelkin, L. (1991). Measurement, Design, and Analysis: An Integrated Approach. Hillsdale, NJ : Lawrence Erlbaum.

Phillips, J.J. (1996). Accountability in human resource management. Houston, TX: Gulf Publishing Company.

Porter, M.E. (1985). Competitive advantage: Creating and sustaining superior performance. New York: The Free Press. 
Purcell, J., \& Hutchinson, S. (2007). Front-line managers as agents in the hRMperformance causal chain: theory, analysis and evidence. Human Resource Management J ournal, 17, 3-20.

Purcell, J., \& Kinnie, N. (2007). Human resource management and business performance. In P. Boxall, J. Purcell, \& P. Wright (eds). The Oxford Handbook of Human Resource Management. Oxford: Oxford University Press.

Purcell, J., Kinnie, N., Hutchinson, S., Rayton, B., \& Swart, J. (2003). Understanding the people and performance link: Unlocking the black box. London: Chartered Institute of Personnel and Development.

Richardson, R., \& Thompson, M. (1999). The impact of people management practices on business performance: A literature review. London: IPD.

Roberts, M.L., \& Wortzel, L.H. (1979). New life determinants of women's food shopping behaviour. Journal of Marketing, 43, 28-39.

Sanz-Valee, R., Sabater-Sanchez, R., \& Aragon-Sanchez, A. (1999). Human resource management and business strategy links: An empirical study. The Journal of Human Resource Management, 10, 655-671.

Schuler, R.S., \& Jackson, S.E. (1987). Linking competitive strategies with human resource management practices. Academy of Management Executive, 1, 207-219.

Sekaran, U. (1992). Research methods for business: A skill building approach. $2^{\text {nd }}$ ed. New York: John Wiley \& Sons.

Snell, S.A., \& Dean, J. (1992). Integrated manufacturing and human resource management: A human capital perspective. Academy of Management Journal, 35, 467-504.

Wright, P.M., \& Gardner, T. (2003). The human resource-firm performance relationship: Methodological and theoretical challenges. In D. Holman, T.D. Wall, C.W. Clegg, P. Sparrow, \& A. Howard (eds). The new workplace: A guide to the human impact of modern working practices. London: John Wiley $\&$ Sons.

Wright, P.M., Gardner, T., Moyniham, L.M., \& Allen, M. (2005). The HR performance relationship: Examining causal direction. Personnel Psychology, 58,409-446. 
Youndt, M., Snell, S., Dean, J., \& Lepak, D. (1996). Human resource management, manufacturing strategy, and firm performance. Academy of Management Journal,39, 836-866.

Zupan, N., \& Kase, R. (2005). Strategic human resource management in European transition economies: Building a conceptual model on the case of Slovenia. International J ournal of Human Resource Management, 16, 882-906.

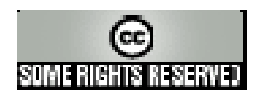

Article's contents are provided on an Attribution-Non Commercial 3.0 Creative commons license. Readers are allowed to copy, distribute and communicate article's contents, provided the author's and Journal of Industrial Engineering and Management's names are included. It must not be used for commercial purposes. To see the complete license contents, please visit http://creativecommons.org/licenses/by-nc/3.0/. 